\title{
ENHANCING SCIENCE STUDENTS' PARTICIPATION IN WRITING ARGUMENTATIVEESSAYS IN BIOLOGY CLASS THROUGH A GENRE-BASED APPROACH (AN ACTION RESEARCH)
}

\author{
Daniel F. Kamengko', Ifoni Ludji ${ }^{2}$, Irna A. Neolaka ${ }^{3}$ \\ Teacher Training and Educational Science Faculty, Artha Wacana Christian University \\ Corresponding author : danikamengko@ukaw.ac.id
}

\begin{abstract}
ABSTRAK
Metode genre based telah dipakai dalam banyak studi. Metode ini juga memberikan banyak kontribusi terhadap peningkatan mutu penulisan dalam berbagai konteks pelajaran. Tujuan dari penelitian ini adalah untuk meningkatkan partisipasi siswa kelas IPA dalam menulis teks argumentasi pada pelajaran biologi dengan menggunakan metode genre based di SMAN 1 Kupang Timur. Penelitian ini menggunakan metode penelitan tindakan kelas yang terdiri dari dua fase. 41 siswa kelas IPA pada SMAN 1 Kupang Timur terlibat dalam penelitian ini. Metode genre based ini diaplikasikan selama empat kali pelatihan selama satu bulan berfokus pada bagaimana siswa menulis teks argumentasi dalam pelajaran biologi. Teks argumentasi siswa dinilai dengan menggunakan penilaian "systemic functional grammar" dalam pemberian pre-test dan postest. Hasil penelitian menunjukan bahwa metode genre based meningkatkan partisipasi dan nilai menulis siswa kelas IPA.

Kata Kunci: pendekatan genre-based, teks argumenatsi, penelitian tindakan, systemic functional grammar

ABSTRACT

Genre-based approach has been used frequently in many studies. It has been shown in any number of studies to contribute to the development of writing across different contexts. The main purpose of the research was to increase science students' participation in argumentative essay writing using a genre-based approach at SMAN 1 Kupang Timur. This study applied an action research method which was comprised of two cycles. 41 science students at SMAN 1 Kupang Timur participated in the study. A genre-based approach was applied four times over the course of a month to teach the students how to write argumentative essays. Students' argumentative essays were measured by the systemic functional grammar framework in pretest and post-test. The research findings indicated that the genre-based approach increased students' participation and scores in argumentative writing.
\end{abstract}

Key words: genre-based approach, argumentative texts, action research, systemic functional grammar 


\section{Indigenous Biologi \\ Jurnal pendidikan dan Sains Biologi \\ 4(1) 2021}

\section{INTRODUCTION}

Argumentative text is widely taught in schools. It is a well-known activity for higher education students (Wu \& Lawrence Jun Zhang, 2017). However, creating good argumentative writing is not easy for students. Many teachers find less than satisfactory results when correcting students' writing tasks (Noroozi \& Hatami, 2019); (Gomez-Laich et al., 2019). Argumentative writing differs from other text types, such as descriptive, procedural, and narrative in that it requires not only writing skills, but also the logical reasoning ability required creating valid arguments.

Argumentative essays can be written by applying several patterns. The first is "one sided style", in which the essay only talks about one point of view (pro side). The second is "clustering style". This style includes one body paragraph which talks about the opposing argument (contra side), while three body paragraphs are dedicated to talking about the pro side. The third is "alternating style", in which one essay contains one contra argument and its rebuttal alternating throughout the argument (Maharani, 2019, p.300).

Students in SMAN 1 Kupang Timur consider argumentative writing to be challenging. Hyland (2003) states that second language learners (L2) identified writing as the most difficult skill, as it has linguistic features, rhetorical organization, and lexicon meaning which may need to be understood but not produced when using other language skills. Jack Croft Richards et al., (2002) agree with that statement; they claim that elaborating their ideas with good vocabulary mastery and implementation in a good paragraph are the weaknesses of many EFL students. Even though, students have passed all writing units, they often fail to produce cohesive, structured argumentative writing texts. The students' writing test results show limited progress on each individual section of the writing assessments. Moreover, students often produce poor English writing because of teachers who still use the traditional teacher based learning approach in which the dominate the teaching and learning process, depriving students of necessary practice. As a result students were passive in the class and their comprehension toward writing remained low (Rogers et al., 2018)

The genre-based approach (GBA) is not a new method for Indonesian schools as it has been part of the Indonesian national curriculum as implemented by the Indonesian government since 2004. Agustin \& Wirza, (2020) points out that one of the efforts of the Indonesian government to increase students' writing ability is through the implementation of the genre-based approach in the curriculum.

There is much literature on improving students' writing skill through a genre-based approach. Knapp \& Megan Watkins, (2005) stated that GBA is very helpful for the students in establishing or developing their writing ability. He argues that, In Australia, GBA is not only helpful for teaching the regular students, but it is also beneficial for the indigenous students (aboriginal students). Research done by Payaprom \& Payaprom, (2020): Amine \& Faiza, (2018)mention that GBA not only increases students' writing ability but also changes students' attitudes towards writing itself. In line with that, de Silva Joyce \& Feez, (2012)mention that GBA increases students' participation in creating different types of texts. They have also explained the three models or procedures in teaching writing through GBA as follow:

- "Modelling text" refers to how teachers model the text types to students. For instance, narrative, descriptive, argumentative and procedure texts

- "Joint construction" refers to collaboration between teachers and students in creating a specific type of text.

- "Independent construction" refers to how students independently create specific types of texts following given instructions.

These stages can be used to enhance students' writing skills in any type of text, particularly in argumentative text. This approach gives a chance to students and teachers to create an essay together. In this way, teachers do not dominate the learning process, but students are also actively involved in creating a writing (Hammond \& B. Derewianka, 2001). As a result, students' participation in writing class increases significantly. 
As this research focuses on increasing students' participation in writing argumentative essays using a genre-based approach, the specific research questions are:

1. Does the Genre-based approach (GBA) increase students' participation in argumentative writing?

2. What are the students' perspectives toward the implementation of GBA?

\section{RESEARCH METHODHODOLOGY}

\section{Research Design}

The research methodology used in this study is action research(Creswell, 2017). The purpose of action research is to explore a practical problem with the intention of developing a solution to the problem. Action research requires the researcher to comprehend a methodical process to solve educational problems and make improvements.

\section{Participants}

The participants of this research were the $11^{\text {th }}$ grade students from SMAN 1 Kupang Timur. The total number of participants was 41 students from the science program. The students previously learned English biology when they were in $10^{\text {th }}$ grade.

\section{Data gathering and Analysis}

The object of the research was the students' participation. The data addresses the action research and was collected through observation and interview. The data was analyzed descriptively in table and graphic forms.

\section{RESULT AND DISCUSSION}

There was a significant improvement on student participation in argumentative writing following the two cycles of the action research; the research was conducted four times over the course of one month. The observation results of the implementation of GBA can be seen in this table: Table1. The comparisons of student participation using the GBA in cycles 1 and 2

Students' participation in writing class using genre-based approach

\begin{tabular}{cc}
\hline Cycle 1 & Cycle 2 \\
\hline $73,25 \%$ & $82,79 \%$ \\
\hline Good & Very good \\
\hline
\end{tabular}

Based on the information above, it can be seen that the students' participation in argumentative writing class increased from 73, $25 \%$ in Cycle 1 to $82,79 \%$ in Cycle 2. This is an increase of $9,54 \%$ from Cycle 1 to Cycle 2 . The increase of the students' participation can be analyzed as follows:

Table2. Student evaluation results in Cycles 1 and 2

\begin{tabular}{ccc}
\hline & \multicolumn{3}{c}{ Scores } \\
\cline { 2 - 3 } Note & Cycle 1 & Cycle 2 \\
\hline Total score & 2740 & 3235 \\
\hline The average score & 68,5 & 78.90 \\
\hline High score & 95 & 100 \\
\hline $\begin{array}{c}\text { Number of students who } \\
\text { passed by achieving at least } \\
\text { the minimum standard score }\end{array}$ & 17 & 29 \\
\hline $\begin{array}{c}\text { Number of students who failed } \\
\text { to reach the minimum } \\
\text { standard score }\end{array}$ & 24 & 12 \\
\hline \begin{tabular}{c} 
Student score percentage \\
\hline
\end{tabular} & $42,6 \%$ & $70,73 \%$ \\
\hline
\end{tabular}




\section{Indigenous Biologi \\ Jurnal pendidikan dan Sains Biologi \\ 4(1) 2021}

As can be seen in the table above, there was a significant increase in students' results in writing using a genre-based approach. The students' average scores increased from 68, 5 in Cycle 1 to 78, 90 in Cycle two. The number of students who passed the writing test based on the minimum standard score (KKM) in the first cycle was 17 students. This is $41,46 \%$ of the total number of students. In Cycle 2, the number of students who passed the writing test increased to $70,73 \%$, a total of 29 students. It can be concluded that students' learning results have shown improvement as indicated by the individual standard indicators $\geq 70$.

Based on the interview results, students gave positive feedback about the implementation of GAB in the class. Below are some student comments related to implementation of GBA.

Student 1

I really like when the teacher gave me time to write my ideas on the whiteboard. I didn't feel embarrassed even though my sentences were not perfect. The teacher supported me and said I am a good student.

Student 2

I like the class situation. The class is fun. We all are moving around and asking questions without hesitation. It really impressed me. I'm wondering why it wasn't like that from the start when I was in $10^{\text {th }}$ grade.

The results from this study indicate that the genre-based approach helped students increase their writing ability and participation in writing class. The results were consistent with studies by Satriani et al., (2012)and Lap \& Truc, (2014)which claim that with GBA students gain better control over writing forms and improve logical thinking in writing paragraphs as well as participating more in the class. Moreover, it also supports a study by de Silva Joyce \& Feez, (2012) which mentions GBA increased student participation in creating a specific type of text.

\section{CONCLUSION AND IMPLICATION}

The findings of the study point out that the students who received process-based instruction in the first phase did not show any improvement. Only some of the students showed improvement while others did not. However, the genre-based instruction in the second phase significantly improved writing performance and participation in the class. After the experiment, the participants became more confident and willing to participate in writing activities.

There are four main implications from the results of the study. First, the use of collaboration teams during the teaching and learning process, as well as appropriate time allotted to each team improved students' ability to create paragraphs. Secondly, teachers must consider using various stages throughout the teaching and learning process to help students be able to compose and express their ideas.

Thirdly, the teachers should use students' errors as authentic teaching resources. Creating portfolios to record the process of learning helps students engage in self-evaluation and contributes to their writing skills (Aydın, 2019).

Fourth, positive responses from the participants are beneficial for motivating teachers to continue using the genre-based approach in their writing classes. However, the critical issue in implementing genre-based teaching is the selection of teaching materials and examples appropriate to students' needs, interests, and proficiency levels (Triastuti, 2020). To face this challenge, as Triastuti suggested, teachers need to learn the process of materials evaluation and adaptation in order to enable them to present suitable input texts.

\section{REFERENCES}

Agustin, A., \& Wirza, Y. (2020). Indonesian teachers perspective towards the use of authentic materials on students communicative competence in EFL classroom. ACM International Conference Proceeding Series, 0-4. https://doi.org/10.1145/3440084.3441215

Amine, B., \& Faiza, S. (2018). the Effect of Process- Genre Approach on ESP Students '. European Journal of Research and Reflection in Educational Sciences, 6(2), 10-14. 
Aydın, İ. S. (2019). Improvement of preservice Turkish teachers' perceived writing self-efficacy beliefs. Kuram ve Uygulamada Egitim Bilimleri, 19(1), 78-94. https://doi.org/10.12738/estp.2019.1.0269

Creswell, J. W. (2017). Research design: Qualitative, quantitative, and mixed methods approaches. Sage publications.

de Silva Joyce, H., \& Feez, S. (2012). Text-based language literacy education: Programming and methodology. Phoenix Education.

Gomez-Laich, M. P., Miller, R. T., \& Pessoa, S. (2019). Scaffolding analytical argumentative writing in a design class: A corpus analysis of student writing. Linguistics and Education, 51, 20-30. https://doi.org/10.1016/j.linged.2019.03.003

Hammond, J., \& B. Derewianka. (2001). "An introduction to genre." The ELT handbook. Cambridge:

Jack Croft Richards, Jack C. Richards, \& Willy A. Renandya. (2002). Methodology in Language Teaching :An Anthology of Current Practice. Cambridge University Press.

Knapp, P., \& Megan Watkins. (2005). Genre, Text, Grammar: Technologies for Teaching and Assessing Writing. University of New South Wales Press Ltd.

Lap, T. Q., \& Truc, N. T. (2014). Enhancing vietnamese learners' ability in writing argumentative essays. Journal of Asia TEFL, 11(2), 63-91.

Maharani, C. (2019). Towards Students' Procedure Text Writing Ability at the First Semester of The Twelfth Grade of MA Al- Hikmah Bandar Lampung in the Academic Year of 2018/2019. 1-86. https://scholar.google.co.id

Noroozi, O., \& Hatami, J. (2019). The effects of online peer feedback and epistemic beliefs on students' argumentation-based learning. Innovations in Education and Teaching International, 56(5), 548-557. https://doi.org/10.1080/14703297.2018.1431143

Payaprom, S., \& Payaprom, Y. (2020). Identifying learning styles of language learners: A useful step in moving towards the learner-centred approach. Journal of Language and Linguistic Studies, 16(1), 59-72. https://doi.org/10.17263/JLLS.712646

Rogers, K., Maxwell, D., \& Robinson, S. (2018). Influences of Academic Success among LowIncome Minority Students: A Qualitative Interpretive Meta-synthesis of Student, Educator, and Parent Experiences. School Social Work Journal, 43(1), 38-59.

Satriani, I., Emilia, E., \& Gunawan, M. H. (2012). Contextual teaching and learning approach to teaching writing. Indonesian Journal of Applied Linguistics, 2(1), 10-22. https://doi.org/10.17509/ijal.v2i1.70

Triastuti, A. (2020). Assessing english pre-service teachers' knowledge base of teaching: Linking knowledge and self-portrayal. Teflin Journal, 31(1), 108-138. https://doi.org/10.15639/teflinjournal.v31i1/108-138

$\mathrm{Wu}, \mathrm{H}$., \& Lawrence Jun Zhang. (2017). Effects of different language environment on Chinese graduate students' perceptions of English writing and their writing performance. System, 65. 